\title{
Strategic niche management from a business perspective: taking cleaner vehicle technologies from prototype to series production
}

\author{
Dedy Sushandoyo and Thomas Magnusson
}

\section{Linköping University Post Print}

\section{Tweet}

N.B.: When citing this work, cite the original article.

Original Publication:

Dedy Sushandoyo and Thomas Magnusson, Strategic niche management from a business perspective: taking cleaner vehicle technologies from prototype to series production, 2014, Journal of Cleaner Production, (74), 17-26.

http://dx.doi.org/10.1016/j.jclepro.2014.02.059

Copyright: Elsevier

http://www.elsevier.com/

Postprint available at: Linköping University Electronic Press

http://urn.kb.se/resolve?urn=urn:nbn:se:liu:diva-107990 
This is the post-print version of Sushandoyo, D \& Magnusson, T (2014): Strategic niche management from a business perspective - taking cleaner vehicle technologies from prototype to series production, Journal of Cleaner Production 74, 17-26. DOI:

10.1016/j.jclepro.2014.02.059. Please refer to the published version and also note that this version might differ slightly from the published version.

\title{
Strategic niche management from a business perspective:
}

Taking cleaner vehicle technologies from prototype to series production

Dedy Sushandoyo \& Thomas Magnusson

Linköping University, Sweden

\begin{abstract}
Strategic niche management has been outlined as a policy approach to assist development and diffusion of cleaner new technologies. Based on a case study describing the efforts of a leading actor in the heavy vehicle industry to develop and commercially introduce hybridelectric vehicles, this paper discusses strategic niche management from the perspective of the manufacturing firm. In particular, the paper analyses experiences from extensive field tests executed in London, tests which involved a number of different manufacturers, hybrid systems and vehicles. The scale of this technological niche added confidence and credibility to the technology and helped opening up an important niche market, which was supported by an extensive subsidy scheme. The analysis shows how the field tests and the subsidies jointly functioned as bridging policies that facilitated an important step in the market formation process. The analysis further points at a critical tension between niches and the volumeoriented business of a major vehicle manufacturer, showing how investments in new technology need to be warranted in market trends and projections of future sales and production volumes to become accepted within a vehicle manufacturer's organization.
\end{abstract}

Key words: strategic niche management, niche market, hybrid vehicle, automotive, clean technology, market formation 


\section{Introduction}

The vehicle industry is currently in a state where the established gasoline/diesel fuelled internal combustion engine (ICE) is being challenged by a number of alternative fuels and powertrain technologies (Orsato and Wells, 2007; Oltra and Saint Jean, 2009; Browne et al, 2012; Calabrese, 2012). Still, many of the proposed cleaner technology alternatives remain in a prototype stage; production and sales on a commercial basis is limited and the established technology dominates the market (Orsato et al, 2012; Sierzchula et al, 2012). The persistent stability of the vehicle industry can be described as a "transition failure" (Wells and Nieuwenhuis, 2012), which can only be resolved through a deeper understanding of the conflicting role of the established vehicle manufacturers. These manufacturers are powerful actors with significant vested interests in established socio-technical structures, but they also retain capabilities which are critical to realize innovation and industrial transformation.

Among the new technologies which have been proposed as cleaner alternatives to the traditional ICE powertrain, the hybrid-electric powertrain stands out, as it has already established a real market presence (Dijk and Yarime, 2010; Magnusson and Berggren, 2011). By the early 2010s, the Japanese manufacturer Toyota had taken an overwhelming lead in hybrid car production, reaching an accumulated production volume of 3 million hybrid cars in February 2011 (Green Car Congress, 2011). In the heavy vehicle sector (trucks and buses over 12 tons) the competitive situation was different, as none of the major manufacturers thus far had attained a position as an obvious leader. ${ }^{1}$ Several manufacturers had indeed developed prototypes, and executed field tests and demonstrations. But in early 2010, no major heavy vehicle manufacturer had actually initiated series production. While some limited market niches did exist for heavy hybrid-electric vehicles, these niches were mainly served by specialized system builders, and production volumes were low.

However in 2010, Volvo - Europe's second largest manufacturer of heavy commercial vehicles - signalled ambitions to take a lead in the development of heavy hybrid-electric vehicles, launching a hybrid bus to the market and initiating series production and sales on a commercial basis. After another two years, Volvo announced plans to cease production of low floor inner-city buses with conventional powertrains and only offer hybrids to the European market. Based on longitudinal case study research, this paper analyses key events that led to these - for a major manufacturer in the heavy vehicle industry - unusually bold strategic decisions. Responding to a need to complement transitions theory with insights related to business management (Geels et al, 2012; Boons et al., 2013); the analysis is made from the perspective of the manufacturing firm. The case study illustrates how a large vehicle manufacturer can take a leading role as an innovator in cleaner new vehicle technologies. A prerequisite for this, however, is that the technology becomes accepted both on the market and within the vehicle manufacturer's own organization. The analysis shows how results from tests executed in competition with other manufacturers, as well as internal synergies, scale economies and projections about future sales and production volumes and are critical to obtain such acceptance.

The theoretical framework is outlined in the next section. Theoretically, the paper departs from Strategic Niche Management (SNM), which is a key concept in theories on sociotechnical transitions. Recent findings on market formation processes and business models for environmental innovation complement the framework. Thereafter, section 3 presents the

\footnotetext{
${ }^{1}$ Japanese Hino (subsidiary of Toyota) may be considered as a leader in hybrid trucks, but in medium duty segments (7-12 tons), primarily serving the domestic market.
} 
research design and methods, and section 4 presents an elaborate description of the case study findings. Section 5 discusses policy and business aspects of environmental innovation based on the findings, and section 6 summarizes the main conclusions.

\section{Environmental innovation and market formation}

\subsection{Cleaner technology introduction and strategic niche management}

Proponents of Strategic Niche Management (SNM) argue that policy makers should initiate local experiments, so called 'niches', to support development and diffusion of cleaner new technologies (Kemp et al., 1998; Hoogma et al, 2002; Smith and Raven, 2012). This is because new technologies are often relatively crude and perform badly according to an established set of performance criteria. Hence they cannot compete with existing technologies, which have evolved over years or even decades to fit with user requirements and regulatory demands. In a corresponding manner, user behaviours and governing institutions have evolved to fit the characteristics of existing technologies. New technologies therefore need to be protected from mainstream market pressures. Niches fill a number of important functions during early stages of technology introduction, including shielding the new technologies from competition, nurturing further development, assisting network building and facilitating a constructive interplay between relevant stakeholders. The argument is rooted in insights from sociology of technology, which suggest that such socio-technical alignment is necessary to construct a social acceptance of the new technology (Rip, 1995). Central in these processes is the articulation of requirements and expectations. Articulation can be related to technical aspects and design specifications, users' needs and demands, as well as regulatory frameworks, which are required to make the new technology competitive (Kemp et al., 1998). Niches thus constitute platforms which enable interactive learning about technical and economic feasibility and they are also instrumental to create institutional connections and adaptations which are necessary for further diffusion of the technology.

While early literature on transition theory and SNM conceptualised niches as isolated experiments (Hoogma et al, 2002), more recent contributions have showed how multiple projects can be accumulated into learning trajectories (Geels and Raven, 2006). In other words, even a failed project can contribute to a long term learning process (Van Eijck and Romijn, 2008). However, to provide direction for such learning processes, it is critical to have a guiding vision (Harborne et al, 2007; Vergragt and Szejnwald Brown, 2007; Shot and Geels, 2008). Moreover, later studies have paid more attention to external processes, contexts and competitive environments surrounding niche development (Shot and Geels, 2008; Kemp and Volpi, 2008; Smith and Raven, 2012).

\subsection{Niche development and market formation}

Shot and Geels (2008) describe niche development as a process in which new technology emerges in the form of experimental research, development and demonstration projects (technological niches). By means of an early version of a product, manufacturers gain market experiences through feedback. Based on these experiences they can modify the product, and again approach the market by means of an improved product. This strategy thus strives to reduce uncertainty by conducting iterative experiments with the aim to exchange information and develop new knowledge (Lynn et al., 1996). The type of interaction depends on the degree of innovativeness of the product. A development project involving a new technology 
typically requires extensive trial-and-error activities. Hence, it demands openness and tight interaction between manufacturers and users (Lettl, 2007).

According to Markard \& Truffer (2008), niches that have a common technology base can be described as emerging technological innovation systems. To be effective, such systems need to facilitate not only experimentation and learning, but also market formation. This is necessary to attract resources, and build social acceptance and legitimacy for the new technology (Bergek et al, 2008). Hence, there may be a need for both supply and demand side policy support. Andersson and Jacobsson (2000) argue that market formation can be described as a stepwise process in which new technologies enter the market via niche (or nursing) markets, i.e. narrow domains of application in which the particular merits of the new technology are of great value, while the deficiencies are not all that problematic. The next step is an increase in terms of production and sales and the product offerings expand to new countries, regions or application contexts. Such "bridging markets" (ibid) are characterised by a higher degree of formation, in which patterns of usage and price expectations become settled. Communication practices between manufacturers and users thus become more standardised. Consequently, new technologies may advance from local experiments in technological niches, via limited adoption in niche markets to bridging markets, which eventually may pave the way to a widespread diffusion on mass markets. Based on an analysis of public support schemes for photovoltaic applications in Germany, Dewald and Truffer (2011) elaborate on these propositions, arguing that different market segments and geographical regions tend to display different structural profiles as they have reached different stages of maturity. Therefore it is insufficient for policy makers to assess the stage of market formation on an aggregate level. Since a broad range of product designs and market contexts may exist simultaneously, it is necessary to distinguish different geographical markets and market segments and consider their individual characteristics.

\subsection{Business perspectives on environmental innovation}

The discussion on cleaner technology introduction, strategic niche management and market formation points at a temporal as well as a structural dimension, which both are critical to understand the challenges associated with environmental innovation from the perspective of the manufacturing firm. Whereas the structural dimension describes critical actors and interactions, the temporal dimension describes market formation as a step-wise process comprising four different stages: technological niche, niche market, bridging market and mass market (figure 1).

\section{FIGURE 1}

Figure 1 Temporal and structural dimensions of cleaner technology introduction and environmental innovation

Apart from fulfilling the needs of users and customers, environmental innovation also aims to fulfil societal objectives in terms of environmental sustainability. Since society rather than individual users tend to benefit from environmental performance, users cannot be expected to drive the demand for environmental performance as they would drive demands directly related to their individual needs. Boons and Lüdeke-Freund (2013) thus describe the development of business models for environmental innovation as a difficult trade-off between 
optimal product performance in terms of e.g. convenience, reliability and cost, and improved environmental performance, addressing the needs of a broader society. Consequently, translating social value into economic value and thereby turning cleaner new technologies into a business cases remains a critical challenge for the manufacturing firm (Loorbach and Wijsman, 2013). Several studies have pointed at policy as a key driver for environmental innovation, showing how policy-driven market stimuli and regulation (or expectations thereof) often are required to motivate firms to investment in the development of cleaner new technologies (Norberg-Bohm, 2000; Visser et al, 2008; Lee et al, 2010). From the perspective of the manufacturing firm this implies that if it focuses its environmental-innovation efforts merely on explicit or perceived user needs, downplaying the role of policy as an important driving force for environmental innovation, it will run the risk of not fully acknowledging the business potential of cleaner new technologies. On the other hand, an undivided focus on policy demands is insufficient, as this may result in products which are unattractive from a user perspective. Hence, the interaction between manufacturers, policy makers and users can be considered a structural foundation of environmental innovation (Magnusson, 2003; Dijk and Yarime, 2010). In this respect, it is important to note that the distinction between policydriven environmental demands and user-driven product requirements is by no means clearcut. Studies of California's early market for hybrid-electric cars illustrate how environmental features can be linked to symbolic meanings, which are valued by certain user groups (Heffner et al, 2007). Consequently, environmental features may influence purchasing decisions even if policy demands are weak.

The manufacturing firm may aspire to take a leading role the market formation, entering the market at an early stage and acting as a prime mover in the innovation system (Carlsson, 1997). The advantages and disadvantages of such pioneering or first mover strategies have been debated in strategic management literature (Olleros, 1986; Lieberman \& Montgomery, 1988; 1998). First movers may establish themselves as technological leaders and gain competitive advantages from patent protection, cost reduction and influence on standardsetting processes. Moreover, first movers may establish strong brands and gain a quality reputation on the market, something that can result in loyal customers. These advantages can be illustrated by studies of Toyota's efforts in the development, production and sales of hybrid-electric cars (Magnusson \& Berggren, 2011; Pohl \& Yarime, 2012; Bergek et al, 2013). Yet, there are potential pitfalls associated with first mover strategies. In particular these are related to extensive technological and market uncertainties, which may result in excessive R\&D spending, long pay-back periods and premature technology choices (Olleros, 1986; Lieberman \& Montgomery, 1988). The emergence of niche markets may not provide a sufficient business rationale for the individual firm to justify market entry. Strategic managers may therefore prefer to bide the time until requirements and expectations have been clearly articulated, standards and regulatory frameworks have been set, technological alternatives have been properly evaluated, bridging markets have started to form and mass markets can be envisioned. Under such circumstances, the firm will remain in an experimental technological niche stage even if the market formation process moves to a consecutive niche market stage.

\section{Research design}

\subsection{Case selection}

The research is based on a single case study research design, focusing on one major heavy vehicle manufacturer: the Volvo Group. This firm manufactures trucks, buses, construction 
equipment, and drive systems for marine and industrial applications. It has around 100,000 employees and production facilities in 20 different countries. Although Europe is the largest market (39\% of Volvo's net sales in 2011), their products are sold all over the world. Ever since 1999, when Ford acquired Volvo's car division, trucks have been the main product. In 2011, Volvo produced 238,391 trucks and 12,786 buses, making the firm one of the world's largest heavy vehicle manufacturers. The case study describes Volvo's efforts in developing and introducing heavy hybrid-electric vehicles. In particular, it focuses on field tests executed in London 2009 - 2010, but the study also includes efforts and initiatives before and after these tests.

\subsection{Data collection}

The study is mainly based on semi-structured face-to-face interviews. In total, 39 interviews were conducted with representatives from different user groups, policy makers, technical universities and bus manufacturers (primarily Volvo, but also other manufacturers). The interviews lasted between 45 minutes and 2,5 hours. Respondents were chosen based on their strategic involvements in the development and market introduction of hybrid buses in general and in the field tests in particular. The interviews with Volvo representatives included managers and engineers on both strategic and operative levels of the organisation. Details about the interviews are provided in Appendix 1. Apart from these formal interviews, informal interviews with bus drivers were made. The data from the interviews was enriched by information from official websites and on-line magazines. These secondary sources were useful to retrieve technical specifications of the hybrid buses, dates related to the field tests, what types of technologies different manufacturers have been developing, and the number of hybrid bus sales. Public policy reports were used to retrieve additional information about how policy actors supported the development and market introduction.

\subsection{Data analysis}

Results from the empirical studies were used as a basis for a longitudinal analysis, outlining a background and discussing succeeding key events and strategic decisions related to Volvo's development, market introduction and sales of heavy hybrid vehicles. The analysis relied on pattern-matching techniques (Yin, 2009), iteratively examining the correspondence between data and theory.

\section{Volvo's heavy hybrid vehicles: Technological development and market introduction}

\subsection{Industry background}

The heavy vehicle industry includes trucks and buses with a total weight above 12 tons. Based on their operation, trucks and buses can be categorised in short distance vehicles (e.g. distribution trucks, waste/refuse trucks, city buses) and long distance vehicles (e.g. longhaulage trucks, coaches). The truck segment is the main market, while the buses constitute a relatively small portion of the sales ( $\sim 10 \%$ in Europe). In activities related to the development and introduction of alternative fuel and powertrain technologies, the bus segment still plays a very important role. In particular, the city bus segment offers a suitable 
application because of the centralised vehicle management and large-scale refuelling stations that professional bus operators have. However, this is also a demanding application because "the drive cycle of a public transit bus puts particularly high stress on the engine, with frequent starts and stops and very little steady operation on the road..." (Lowe et al 2009:22). Another advantage is that city bus operators tend to use the bus for the entire lifespan of the vehicle, i.e. 10-15 years. By contrast, new distribution trucks are generally used in 2-4 years, before the first customer sells them further to other operators. Accordingly, the bus operator's required payoff time for added investment costs related to fuel saving equipment tends to be longer. Moreover, the city bus market is heavily influenced by municipal authorities, who frequently adopt local regulations to cut emissions beyond national standards.

In Europe, about 25,000 city buses are sold each year. The 50 biggest networks of bus operators purchase around $65 \%$ of these buses. Five large manufacturers (Daimler/Evobus, MAN, Iveco, Volvo, and Scania) dominate the market, retaining a joint market share of $73 \%$ in 2012 (UITP, 2013). Within the European Union, Great Britain stands out as the leading market, where around 3,000 city buses are sold annually.

\subsection{Hybrid-electric vehicle configurations and applications}

Whereas a traditional automotive powertrain relies on the internal combustion engine as a single source of motive power, a hybrid-electric powertrain uses a combination of power sources: an internal combustion engine and one or more electric motors, and some type of energy storage device. Hybrid technology enables the powertrain to recuperate braking energy, which is converted into electric energy. The electric energy is saved in the energy storage and used when necessary. Apart from the potential fuel saving, hybrid technologies provide other benefits such as comfort (i.e. less noise, smoother acceleration and deceleration), reduction of emissions $\left(\mathrm{CO}_{2}, \mathrm{NO}_{\mathrm{x}}\right.$, particulates), and potentially lower maintenance cost (e.g. reduced wear on brakes). The development of hybrid vehicles is however a challenging task for the vehicle manufacturer, since it involves a significant amount of new knowledge which needs to be integrated with existing knowledge in a coherent way.

There are two main hybrid electric configurations: series and parallel. Each of them has different characteristics with regard to cost, performance attributes, and feasible applications. In a series hybrid, the combustion engine is connected to an electric generator to produce electricity. The electricity can either be used to charge the energy storage or be directly fed to an electric motor by which the vehicle is propelled. This electric machine enables the vehicle to effectively recuperate braking energy in frequent stop-and-go traffic. The series hybrid configuration facilitates smooth acceleration and deceleration. Furthermore, this configuration allows the combustion engine to be run at a constant point with optimal fuel efficiency and low emissions. Because the series configuration employs a full scale diesel engine, as well as two separate powerful electric machines (generator and motor), the product cost is very high. Furthermore, because the energy is converted twice, from motive energy to electric energy and then back to motive energy; the vehicle is less energy efficient when it is operated in highway traffic (Guzzella and Sciaretta, 2005).

In a parallel hybrid configuration, the combustion engine is supported by an electric motor. The electric motor assists the engine in cases when the vehicle requires extra torque (e.g. takes off from standstill and hill-climbs). Because the motive power that is required to propel the vehicle is shared by the combustion engine and the electric motor, the sizes of these devices can be smaller. Compared to a conventional diesel engine powertrain, the parallel 
hybrid electric configuration allows the combustion engine to be operated in a more efficient range. The engine and electric motor are mechanically coupled and linked to a transmission (including clutch and gears) that propels the vehicle via a drive axle. In contrast to the series hybrid, the parallel hybrid does not require a separate electric generator (Guzzella and Sciaretta, 2005). Therefore the parallel configuration makes it possible to reach a lower product cost. However, since the electric motor and the combustion engine are jointly connected to the mechanical transmission in a parallel hybrid, significant integration efforts are needed. Consequently, the development requires substantial R\&D investments.

For major heavy vehicle manufacturers, possible synergies between different vehicle types are an important aspect. In general, hybrid vehicles will be most beneficial in driving conditions characterised by frequent starts and stops, such as inner-city driving. Both series and parallel hybrid configurations are feasible options in such conditions. For vehicles which drive longer distances with little possibility to recuperate energy, series hybrids are unfeasible; here parallel hybrid configurations will be more efficient. Table 1 compares the feasibility for series and parallel hybrids in different heavy vehicle applications.

Table 1 Feasibility for hybrid configurations in heavy vehicle applications

\section{TABLE 1}

\subsection{Volvo's early efforts in hybrid-electric vehicle development}

Volvo's engagement with hybrid vehicles can be traced back to the mid-1980s, when the firm began advanced engineering activities, experimenting with various technology alternatives. In 1992, Volvo showed a concept car which was based on a series-hybrid configuration. Instead of a traditional internal combustion engine in combination with an electric propulsion system, the car comprised a small gas turbine which was very clean in terms of exhaust emissions. Volvo subsequently developed and implemented an up-scaled version of the microturbinebased series hybrid powertrain in a concept truck and a concept bus, which they showed in 1995 - 96. The R\&D enjoyed public financial support from the Swedish business development council.

Following the display of their concept vehicles, Volvo developed a number of serieshybrid prototype cars with internal combustion engines. In the late 1990s, the company also developed a truck prototype with a similar series-hybrid configuration. The truck was leased to a distribution company in Gothenburg. Volvo also developed two inner-city bus prototypes using their microturbine series-hybrid. The municipal city bus operator Göteborgs Spårvägar purchased and operated these vehicles in regular traffic in 1999-2000 (Rader-Olsson, 2000). Low $\mathrm{NO}_{\mathrm{x}}$ and particulate emissions (10\% of the prevailing Euro II requirements) were primary targets of the project. However, as the buses were not as reliable as conventional buses the interest from Göteborg Spårvägar declined. Moreover, Volvo learned that it was difficult to show any gains in fuel efficiency with these series-hybrid configurations. The development and demonstration of these hybrid trucks and buses was part-funded by the Swedish Transport and Communications Research Board.

During the 2000s, Volvo obtained public funding for hybrid technology development via the Swedish Green Vehicle programs, the Swedish Energy Agency and the Strategic Vehicle Research and Innovation program. In the early 2000s, Volvo managers initiated a study of peak oil scenarios and their potential consequences for fuel price developments and in 2002 
they started an advanced engineering project to investigate which type of hybrid would offer the best combination of fuel efficiency, robustness and cost-effectiveness. The project pointed at a parallel hybrid as a preferred configuration, arguing that although a series hybrid could offer benefits in very specific drive cycles, the parallel hybrid was the most versatile solution, offering a lower unit cost and superior fuel efficiency in a broad range of applications. Volvo engineers implemented this powertrain concept in prototype vehicles, running field tests and demonstrations for managers and selected customers.

In 2006, Volvo's CEO Leif Johansson publically announced that they intended to launch a hybrid-electric truck to the market in late 2009. In an interview, Volvo's project manager emphasized that raised fuel prices rather than regulatory demands and governmental subsidies would make the hybrid commercially attractive. However, it was still difficult to justify the development and there was internal resistance against the project. A senior manager recalls:

"I can say that Leif Johansson had pretty though time with some of his managers, that he was very brave to stand behind the decision and to be very supportive. Because there was a lot of criticism in the organisation that it will take a lot of time to get commercial and in reality these will not be competitive products for a decade or something like that. ... Certainly we were a group of people who thought that this decision was right, but I would say $80 \%$ of the engineers were very sceptic." (Senior manager, Volvo Buses, 2012)

Volvo's engineers opted for a parallel hybrid in which they integrated the electric motor/generator with the diesel engine and an automatic gearbox. Significant R\&D investments would be needed to develop this configuration, but it would be more versatile than the series hybrid and the potential for cost reduction to reach a competitive price level was greater. The engineers expected to reduce fuel consumption by up to $20 \%$ in refuse truck applications, $15-20 \%$ in distribution truck applications and up to $30 \%$ in inner-city bus applications. Between 2007 and 2009 Volvo continued working with engineering, prototype manufacturing and preparations for market launch. Field tests were important parts of this. In June 2009, Volvo announced that they had delivered six hybrid buses for field tests in innercity London.

\subsection{The London field tests}

8,500 buses operate in London in 24 hours per day/7 days a week, serving 6.4 million journeys every day. This is the biggest city bus fleet in Europe. London has 700 different routes and 19,500 bus stops. In London, the Mayor has a very strong constitutional influence on the local transport. According to the Climate Change and Environment Programme Coordinator at Transport for London (TfL)2, the Mayor 2000-2008 Ken Livingstone "had environment very firmly on the top of his agenda" (interview 2012). Particularly due to localair quality issues, TfL thus initiated a detailed study comparing a range alternative fuels and powertrains for city buses. The benefits and challenges related to each alternative fuel were examined according to 4 dimensions: practicality, cost, environment, and readiness. The study concluded that hybrid buses were the best technology alternative and in 2006, the Mayor announced that he expected London to have 1000 hybrid buses in operation by the Summer Olympics 2012.

\footnotetext{
${ }^{2}$ Local government body responsible for most aspects of the transport system in Greater London.
} 
To initiate a product evaluation process, the city of London through TfL invited manufactures to conduct field tests of hybrid buses. The buses were to be operated in regular traffic. The tests were financially supported by the British Government through the Green Bus Fund $^{3}$. Among the major European heavy vehicle manufacturers, Volvo was the only one that participated ${ }^{4}$. The other participating manufacturers were specialised hybrid system suppliers. Volvo tested their parallel hybrid configuration whereas the other manufacturers presented products based on series hybrid configurations (BAE Systems, Enova and Siemens) and complex/blended hybrid configurations (Allison). In total, 56 buses were involved in the test.

"We bought 56 buses and we especially chose a wide manufacture range and a wide range of engine types, battery types ... We really wanted to mix and match and try as much as possible, and see how they operated." (TfL's Climate Change and Environment Coordinator, 2012).

During the test period, TfL repeatedly evaluated the performance of the hybrid buses and then informed the manufacturers about the results. TfL also organised regular meetings with the manufacturers and the operators.

Arriva, which is one of five major city bus operators in London, operated the six Volvo buses. Volvo UK's product engineering manager explained that the number of prototypes was unusually large - normally Volvo would only build one or two prototypes. During the tests, Volvo and Arriva managers had technical meetings every three months to discuss the progress. Immediate meetings were also held as major issues arose. At operational level, Volvo assigned a team of maintenance technicians (4-5 people) from Volvo's UK dealer to work in the bus operator's garage. There were also regular visits from a technical team from the main R\&D facility in Sweden. In case of technical problems, the Volvo team could respond immediately. Volvo recalled the buses twice and sent them back to their main R\&D facility for technical adjustments (e.g. software updates). Moreover, a training programme for the drivers was arranged to provide information on the differences between hybrid and conventional buses and train the drivers.

In 2009, TfL conducted a survey among passengers. The survey involved 1,213 passenger interviews, conducted on different hybrid bus models from different manufacturers. The majority of interviewed passengers were satisfied with the hybrid bus and in the ratings there were few differences between the different manufacturers' bus models. However, relatively few interviewed passengers mentioned aspects that could be specifically attributed to the hybrid powertrain such as quietness (not noisy), smooth ride, environmentally friendly (low emissions) (TfL, 2009). Moreover, the drivers responded positively to the hybrid buses because of their smoothness and comfort and the vehicle mechanics in the bus operators' garages were also pleased with the hybrid buses.

According to TfL's Climate Change and Environment programmes coordinator, there is always a little bit of distrust in new technologies and worries that it might break down.

\footnotetext{
${ }^{3}$ In the Green Bus Fund programs, the British Government, Department for Transport (DfT) provided grants for bus companies and local authorities that introduce any types of technologies (including hybrid) that were able to achieve a $30 \%$ reduction in its GHG emissions compared to the average Euro III diesel bus of the same total passenger capacity. The total budget granted for the Green Bus Fund I (2009), II (2010), III (2011) and IV (2012) programs was $£ 95$ million (DfT, 2013).

${ }^{4}$ Volvo was not the only major European manufacturer that had such ambitions, though. Interviews with managers at another of the industry dominants reveal that also this firm ran a development project which aimed to present a product which would compete for hybrid bus orders to London by 2012 .
} 
However, the tests showed that that the new technology could operate in a big bus fleet without any significant operational problems. TfL's Operation Director confirmed that the field test boosted the operators' confidence in the new technology:

"We have proved that it is a reliable technology. When we started, some operators would be reluctant and sort of hesitant to the technology. Now there is no reluctance to the technology and everybody is comfortable to taking it on ... One of our operators just ordered 75 hybrids. You wouldn't order 75 if you are not comfortable with the technology" (TfL's Operation Director, 2012).

The reliability was noted in TfL's evaluations, which show that the availability for Volvo's hybrid bus was around $97 \%$. This result was a significant achievement.

"For hybrid vehicles it is remarkable if you come to an availability that is $60-70 \%$. The availability of a standard diesel vehicle is $67 \%$. So, $97 \%$ availability is a great achievement." (Volvo's hybrid programme director, 2012)

Furthermore, the fuel saving was above 30 per cent, a figure which exceeded Volvo's expectations. The hybrid bus appeared not only favourable in inner-city traffic, but also in transit traffic between inner-city regions and suburban areas. Figure 1 presents results from TfL's evaluations in terms of availability and fuel savings.

\section{FIGURE 2}

Figure 2: Results from field tests in London. A-D denotes Volvo's four competitors. Competitors $A, C$ and $D$ have several positions in the diagram because they collaborated with several operators. (Source: TfL)

TfL's evaluations also indicated that there was a second strong competing product in the market, offered by another manufacturer. According to TfL's Operation Director, the competition between different products and different manufacturers was a very important part of the field tests as it made it possible to see which alternative that would be the most suitable for the local conditions. Moreover, he anticipated that the competition would facilitate important cost reductions.

"One of the ways that hybrid buses can become commercially viable in the future is through competition between manufacturers to drive the price down." (TfL's Operation Director, 2012).

Based on the positive results of the field test, the bus operator Arriva ordered 152 hybrid buses from Volvo. According to Arriva's engineering director, they did not need to do field tests in other cities since the buses had worked so well in London. Another major bus operator, Go Ahead, procured 45 Volvo hybrid buses without conducting any prior field tests. Go Ahead's engineering director explained that the positive results from Volvo's and Arriva's tests in London were sufficient to justify the purchasing decision. Still the director stated that without subsidies from the government, it would be difficult to justify procurement of hybrid 
buses. However, the hybrid bus orders from operators such as Arriva and Go Ahead were not solely driven by governmental subsidies and the performance shown in the London field tests. It was also because of TfL's specifications, which entailed demands on environmental performance which essentially forced bus operators to operate hybrid buses.

\subsection{Market launch and commercial sales}

While running field tests of hybrid buses in London, Volvo also ran field tests of a hybrid bus in Gothenburg, Sweden, in collaboration with the municipal public transport company Göteborg Spårvägar. Moreover, the refuse handling and recycling companies Renova and Ragn-Sells operated Volvo hybrid trucks in Gothenburg and Stockholm respectively. Through its subsidiary Renault Trucks, Volvo also delivered four refuse trucks with hybrid power trains to Veolia Propreté, one of the world's largest companies in refuse handling, commencing operations in Paris and London during the autumn 2009. However, the results from the refuse trucks field tests did not convince product managers at Volvo's truck divisions about the business potential of hybrid trucks. Fuel efficiency did improve significantly. But since the number of miles that a refuse truck operates is limited, the fuel efficiency did not translate into sufficient savings to justify the extra investment cost of a hybrid. Volvo's plans for a full scale market launch of a hybrid-electric truck were therefore postponed. By 2013, only a limited number of vehicles had been delivered to selected customers.

By contrast, Volvo's bus division maintained their plans to introduce a hybrid bus to the market and they initiated series production in 2010. The sales increased rapidly as the hybrid bus became commercially available and Volvo received orders for about 200 hybrid buses during this first year. In 2011, Volvo launched a second version of their hybrid bus and they also announced that they would launch an articulated hybrid city bus in 2012. By early 2013, Volvo had sold about 1000 hybrid buses since the initial market launch, a figure that positioned them as the leading heavy hybrid bus manufacturer. They had delivered hybrid buses to about 20 different countries, most of them in Europe but significant orders had also been signed also outside Europe, e.g. to Curitiba in Brazil. Still, a remarkable $25 \%$ had been sold in Great Britain. The managing director of Volvo Buses U.K. sales office explained that the new technology had made a significant impact on the organization:

"I think that the difference is that we previously just sold products, buses, and we didn't care too much about it. I think we are now selling ... the future products; we are selling something that is not a bus anymore. It's delivering something that we really believe is good for environment. It's more philosophy now and I think this is something to be quite proud of. So, selling a technology, it's selling the future, and I think that is the difference from where we have been."

(Managing Director, Volvo Buses U.K., 2012).

In 2012, Volvo managers announced that they had decided to cease production of low-floor inner-city buses with conventional powertrains and only offer hybrids by January 2014, as the new European emissions regulation Euro VI would take effect. Since the low floor city bus is the largest city bus segment in Europe, this decision was expected to have a significant effect on the sales and production volume. Table 2 summarises Volvo's development and market 
introduction of heavy hybrid vehicles, as well as related initiatives from policy makers and user involvement along a timeline.

Table 2 Volvo's development and market introduction of heavy hybrid vehicles, related initiatives from policy makers and user involvement

\section{TABLE 2}

Volvo subsequently expanded their hybrid vehicle R\&D and the firm is currently (in 201213) developing a plug-in hybrid bus. In terms of technological configuration, this is similar to the current hybrid bus, but it uses a larger and more powerful battery package and equipment that makes it possible to charge the battery via the main electrical grid. As a result, the plug-in hybrid bus will use electricity as the primary source of energy and diesel fuel as a supplement. Compared with conventional diesel-fuelled city buses, the plug-in hybrid bus is expected to reduce total energy consumption by up to $65 \%$, lower carbon-dioxide emissions by more than $75 \%$ (assuming that the electricity is generated from renewable sources), and reduce noise levels significantly. According to a senior manager at Volvo Buses, field tests will be executed in 2013-14 and market launch is planned for 2015.

\section{Discussion}

\subsection{Policy aspects: protection or competition?}

The case study describing Volvo's efforts developing and introducing heavy hybrid-electric vehicles specifically points at the critical role played by the field tests in London. These tests brought confidence and credibility to the technology and it helped to open up an important initial market segment- inner-city buses. Thus it marked a transition from a technological niche stage characterised by pre-commercial prototyping, testing and demonstration activities, to a commercial and production oriented niche market stage. The London field tests were certainly not the only local learning experiments that Volvo engaged in during their development of heavy hybrid-electric vehicles. The firm conducted field tests with hybrid trucks and buses in Gothenburg, Stockholm and Paris as well, and they also had previous experiences from a number of field tests with earlier prototypes. Also these tests were organized as collaborative learning experiments involving manufacturers, users and policy makers. Still, the London field tests stand out in terms of its scale, involving different manufacturers and a large number of hybrid-electric vehicles.

Literature on strategic niche management and socio-technical transitions has pointed at the critical role of niches to shield and protect new technologies from competitive pressures (Smith and Raven, 2012). Still in order to advance from early experimental stages, new technologies need to be exposed to competition. The organization of the field tests in London provide an important clue on how cleaner new vehicle technologies can progress from "technological niches" (Schot and Geels, 2008) to a stage of production and sales on a commercial basis. In particular, the scale of the London tests facilitated a certain competition, which was favourable for the progress of the technology. Notably, this was not a competition between new and existing powertrain technologies. Rather, it was a competition between different manufacturers and different technological configurations and designs. The 
complexity of a vehicle means that even if you stipulate a certain system technology, a significant number of design options will remain. These options relate both to overall systems configuration and detailed selection of component technologies. As illustrated by TfL's evaluations, different alternatives may produce a large variety of results. The involvement of different hybrid buses characterised by different technological configurations and designs made it possible to evaluate several alternatives, something that lessened the risk of a premature disqualification of the technology. Moreover, a favourable competition could be realised by involving multiple manufacturers. This reduced the risk that one single actor would become too dominant; a problem that has been observed in previous experiments with alternative vehicle concepts (Hoogma, 2002). What is more, the existence of several competing manufacturers may also result in incentives for cost reductions at a later stage. A prerequisite for such an organization, however, is that the coordinating policy maker possesses sufficient technological expertise and resources to support the field tests and make independent evaluations. ${ }^{5}$

Andersson and Jacobsson (2000) argue that policy makers can promote the diffusion of cleaner technologies by stimulating so called bridging markets. Such markets constitute essential links between initial niche markets and mass markets. Our analysis of Volvo's early efforts in the development and market introduction of heavy hybrid vehicles focuses on a preceding step in the market formation process, the one between the technological niche and the niche market. The scale of the field tests, TfL's expertise and the scope of TfL's operations in London meant that TfL had a major influence on niche market formation. Results from the field tests could be used as references for purchasing decisions both in London and elsewhere. The field test also had a significant impact on national policies. One noteworthy example is the Green Bus Fund, which provided financial support for purchase of hybrid-electric city buses. This funding programme was particularly important for the rapid expansion of the hybrid city bus sales in Great Britain.

From the vehicle manufacturer's perspective, market entry is associated with major investments. This is not only related to $R \& D$, but also to supply chain, production, marketing, sales and service infrastructure. Therefore decisions to enter the market are very critical. The case analysis shows how the London field tests and the Green Bus Fund had a positive influence on Volvo's efforts to enter the market. Although TfL's initiative can be characterised as a technological niche, it also stretched forward to a niche market stage, because of its scale and its element of competition. The Green Bus Fund, on the other hand, stimulated initial niche market development, but it also stretched backwards to the technological niche. Its establishment was directly influenced by the London field tests ${ }^{6}$ and, correspondingly, the Green Bus funding program provided financial means which helped realising the field tests. Thus, paraphrasing Andersson and Jacobsson (2000), these initiatives can be characterised as bridging policies that helped linking the technological niche to an important market niche for heavy hybrid vehicles.

\subsection{Business aspects: niches or volumes?}

Bergek et al (2008) argue that formation of expectations and visions are essential for legitimation of new technologies, and SNM literature has pointed at the existence of a long-

\footnotetext{
${ }^{5}$ This finds a parallel in the evolution of the mobile telecom industry, which points at the importance of competition between manufacturers and the existence of technologically skilled independent public agencies (Berggren and Laestadius, 2003).

6 This was confirmed by TfL's Operations Director, who stated that "I think it's fair to say that the Green Bus Fund exists because London tries the vehicle and creates a market” (interview, 2012).
} 
term guiding vision as essential to build social acceptance (Vergragt and Szejnwald Brown, 2007; Shot and Geels, 2008). Through his public announcement of a development project aiming for the market, Volvo's CEO articulated a vision that the firm would attain a leading role as a manufacturer of heavy hybrid vehicles. Worth noting is that the first announcement stated that Volvo planned to introduce a hybrid-electric truck, not a bus. Since truck production is by an order of magnitude larger than bus production, the introduction of a hybrid truck indicated significant volumes. Moreover, the sharing of a technology platform across a variety of products pointed at even higher volumes. These were necessary to justify the investment needed to develop a product that could be manufactured and sold on a commercial basis. Moreover, they indicated possibilities of synergies and cost reductions. Volvo directors anchored their decision to launch heavy hybrid vehicles in projections of significantly raised fuel prices. With such projections, investments in fuel saving technology could be justified in financial terms.

Still, for a manufacturing firm that introduces a cleaner new technology, it makes sense to enter the market via segments where environmental demands are - or can become - essential parts of the purchasing decision. Moreover, a manufacturer that adopts a first mover strategy may have to take an active role in the shaping of such environmental demands, either in direct interaction with users, or through interaction with policy makers, promoting the new technology as a benchmark for regulatory standards and demands on environmental performance (Magnusson, 2003; Heffner et al, 2007; Dijk and Yarime, 2010). Volvo's introduction of hybrid-electric vehicle technology in city bus applications and their delivery of hybrid buses to the field tests in London fit well with such an entry strategy. In London, the bus operators' buying decisions were directly influenced by TfL's environmental demands, which in turn were greatly influenced by the results of the field tests. And the tests were executed in close collaboration with the hybrid bus manufacturers.

Dewald \& Truffer (2011) argue that since different market segments may display different structural profiles, policy initiatives to support market diffusion of cleaner new technologies must be adapted to local conditions. The analysis of Volvo's efforts in developing and introducing heavy hybrid-electric vehicles arrives at a somewhat contradictory proposition. In London, TfL's environmental agenda followed the Mayor's vision to transform the public transport in London, making it less polluting and more attractive. By contrast, Volvo's vision was to attain a leading position as a global manufacturer of heavy hybrid vehicles. Therefore, from Volvo's perspective it was important that the technology was applicable in a variety of applications; that it would fit diverse customer demands in different market segments, at various locations. In other words, the technology had to be prepared to enter not only a limited niche, but eventually also a mass market. Managers and engineers at Volvo thus had to ensure that the development did not become imprisoned by specific arrangements and local requirements. It was important to pursue a strategy that aimed beyond London, Great Britain and inner-city buses. On the one hand, the specific arrangements that surrounded the London field tests provided invaluable support and useful protected spaces which made it easier for the firm to enter the market. But on the other hand a variety of local demands and rules could entail a risk of market fragmentation, and a risk that the hybrid bus development would become isolated without any chances of achieving synergies with the heavy truck business.

\section{Conclusion}

Responding to a need to extend transitions theory with insights related to business management, this paper has analysed strategic niche management from the perspective of a 
major heavy vehicle manufacturer. The analysis shows that although policies for protection and shielding is necessary to move cleaner new technologies from stages of experimental prototyping towards production and sales on a commercial basis, exposure to competition is equally important. The analysis further suggests that the dilemma between protection and competition during early stages of market formation can be resolved by involving several manufacturers in testing activities, while still shielding the new technology from existing socio-technical structures. A prerequisite for this, however, is that the testing and evaluation activities have a sufficient scale. Moreover, they must be supported by independent technological expertise and resources.

An important policy implication that can be derived from the analysis is the importance of policies that link different stages of market formation. Such bridging policies may either stretch forward to the next stage, as exemplified by the London field tests or stretch backwards to a proceeding stage, as exemplified by the Green Bus Fund. Both forward stretching and backwards stretching policies are essential to promote market formation, and ideally they should be coordinated with each other.

The analysis further points at a critical tension between narrow niches and the volumeoriented business of a major vehicle manufacturer, where significant investments are needed to take new technologies from prototype to series production. For a vehicle manufacturer, it is important to justify these investments. Acceptance on the market is important for this and market entry via niches is thus a useful strategy. However, building social acceptance and legitimacy within the vehicle manufacturer's own organisation appears just as important. For this purpose, internal synergies, scale economies and projections of future sales and production volumes remain critical.

\section{Acknowledgement}

We are grateful for constructive comments on earlier manuscripts provided by Christian Berggren and two anonymous reviewers. The research has been executed as part of the Kite research program which is financially supported by Riksbankens Jubileumsfond. Financial support has also been obtained from the Lars Erik Lundberg Foundation for Research and Education.

\section{References}

Andersson, B.A., Jacobsson, S., 2000. Monitoring and assessing technology choice: the case of solar cells. Energy Policy 28, 1037-1049.

Bergek, A., Jacobsson, S. Sandén, B., 2008. 'Legitimation' and 'development of positive externalities': two key processes in the formation phase of technological innovation systems. Technology Analysis and Strategic Management 20, 575-592.

Bergek, A., Berggren, C., Magnusson, T., Hobday, M., 2013. Technological discontinuities and the challenge for incumbent firms: Destruction, disruption or creative accumulation? Research Policy 42, 1210-1224

Berggren, C. and Laestadius, S. 2003. Co-development and composite clusters- the secular strength of Nordic telecommunications. Industrial and Corporate Change 12, 91-114.

Boons, F., Montalvo, C., Quist, J., Wagner, J., 2013. Sustainable innovation, business models and economic performance: an overview, Journal of Cleaner Production 45, 1-8. 
Boons, F., Lüdeke-Freund, F., 2013. Business models for sustainable innovation: state-of-theart and steps towards a research agenda, Journal of Cleaner Production 45, 9-19.

Browne, D., O’Mahony, M., Caulfield, B., 2012. How should barriers to alternative fuels and vehicles be classified and potential policies to promote innovative technologies be evaluated? Journal of Cleaner Production 35, 140-151.

Calabrese, G. (Ed.), 2012. The greening of the automotive industry. Palgrave Macmillan, Hampshire.

Carlsson, B., 1997. Technological systems and industrial dynamics. Kluwer Academic Publishers, Norwell

Dewald, U. and Truffer, B., 2011. Market Formation in Technological Innovation SystemsDiffusion of Photovoltaic Applications in Germany. Industry \& Innovation 18, 285-300.

DfT, 2013. Background to the Green Bus Fund. URL:

https://www.gov.uk/government/collections/background-to-the-green-bus-fund (Acc. 27 October, 2013).

Dijk, M. and Yarime, M., 2010. The emergence of hybrid-electric cars: Innovation path creation through co-evolution of supply and demand. Technological Forecasting and Social Change 77, 1371-1390.

Eijck, van J.A.J. and Romijn, H.A., 2008. Prospects for Jatropha biofuels in developing countries : an analysis for Tanzania with strategic niche management. Energy Policy 36, 311-325.

Geels, F.W., Kemp, R., Dudley, G., 2012. Findings, conclusions and assessments of sustainability transitions in automobility, in Geels, F.W., Kemp, R., Dudley, G., Lyons, G. (Eds.) Automobility in transition? A socio-technical analysis of sustainable transport, Routledge, New York, 205-228.

Geels, F. and Raven, R., 2006. Non-linearity and Expectations in Niche-Development Trajectories: Ups and Downs in Dutch Biogas Development (1973-2003). Technology Analysis \& Strategic Management 18, 375-392.

Green Car Congress, 2011. Cumulative worldwide sales of Toyota hybrids top 3M units. URL: http://www.greencarcongress.com/2011/03/cumulative-worldwide-sales-of-toyotahybrids-top-3m-units.html (Acc. 17 October, 2011)

Harborne, P., Hendry, C., Brown, J., 2007. The Development and Diffusion of Radical Technological Innovation: The Role of Bus Demonstration Projects in Commercializing Fuel Cell Technology. Technology Analysis \& Strategic Management 19, 167-187.

Heffner, R.R, Kurani, K.S., Turrentine, T.S., 2007. Symbolism in California's early market for hybrid electric vehicles. Transportation Research Part D: Transport and Environment $12,396-413$

Hoogma, R., Kemp, R., Schot, J. and Truffer, B., 2002. Experimenting for Sustainable Transport. The approach of Strategic Niche Management, Spon Press, London.

Kemp, R., Schot, J., Hoogma, R., 1998. Regime Shift to Sustainability through Process of Niche Formation: the Approach of Strategic Niche Management. Technology Analysis \& Strategic Management 10, 175-195.

Kemp, R. and Volpi., M., 2008. The diffusion of clean technologies: A review with suggestions for future diffusion analysis. Journal of Cleaner Production 16, 14-21. 
Lettl, C., 2007. User involvement competence for radical innovation. Journal of Engineering and Technology Management 24, 53-75.

Lee, J., Veloso, F.M., Hounshell, D.A., Rubin, E.S., 2010. Forcing technological change: a case of automobile emissions control technology development in the US. Technovation 30, 249-264.

Lieberman, M. B. and Montgomery, D. B., 1988. First-mover advantages. Strategic Management Journal 9, 41-58.

Lieberman, M. B. and Montgomery, D. B., 1998. First-mover (dis)advantages: retrospective and link with the resource-based view. Strategic Management Journal 19, 1111-1125.

Lowe, M., Aytekin, B., Gereffi, G., 2009. Public Transit Buses: A Green Choice Gets Greener, Manufacturing Climate Solutions, Centre on Globalization, Governance \& Competitiveness (CGGC), Duke University, Durham (NC). available online URL: http://www.cggc.duke.edu/environment/climatesolutions/greeneconomy_Ch12_TransitB us.pdf (Acc. 25 March 2013)

Loorbach, D. and Wijsman, K., 2013. Business transition management: exploring a new role for business in sustainability transitions. Journal of Cleaner Production 45, 20-28.

Lynn, G.S., Morone, J.G., Paulson, A.S., 1996. Marketing and Discontinuous Innovation: The Probe and Learn Process. California Management Review 38, 8-37.

Markard, J. and Truffer, B., 2008. Technological innovation systems and the multi-level perspective: Towards an integrated framework. Research Policy 37, 596-615.

Magnusson, T., 2003. Commercialising cleaner new technologies: the case of microturbine generators. Technology Analysis \& Strategic Management 7, 349-361.

Magnusson, T. and Berggren, C., 2011. Entering an era of ferment-radical vs incrementalist strategies in automotive power train development. Technology Analysis \& Strategic Management 23, 313-330.

Norberg-Bohm, V., 2000. Creating incentives for environmentally enhancing technological change: Lessons from 30 years of U.S. energy technology policy. Technological Forecasting and Social Change 65, 125-148.

Olleros, F. J., 1986. Emerging industries and the burnout of pioneers. Journal of Product Innovation Management 1, 5-18.

Oltra, V. and Saint Jean, M., 2009. Variety of technological trajectories in low emission vehicles (LEVs): A patent data analysis. Journal of Cleaner Production 17, 201-213.

Orsato, R.J., Dijk, M, Kemp, R., Yarime, M, 2012. The electrification of automobility: the bumpy ride of electric vehicles towards regime transition, in Geels, F.W., Kemp, R., Dudley, G., Lyons, G. (Eds.): Automobility in transition? A socio-technical analysis of sustainable transport, Routledge, New York, 205-228

Orsato, R.J. and Wells, P., 2007. U-Turn: The Rise and Demise of the Automobile Industry, Journal of Cleaner Production 15, 994-1006.

Pohl, H., Yarime, M., 2012. Integrating innovation system and management concepts: The development of electric and hybrid electric vehicles in Japan. Technological Forecasting and Social Change 79, 1431-1446. 
Rader-Olsson, A., 2000. Clean vehicles with electric drive: Final report from the Swedish research, development and demonstration program on electric and hybrid vehicles 19932000, KFB-Rapport 2000:23, Stockholm

Rip, A., 1995. Introduction of new technology: Making use of recent insights from sociology and economics of technology. Technology Analysis \& Strategic Management 7, 417-431.

Sierzchula, W., Bakker, S., Maat, K., van Wee, B., 2012. Technological diversity of emerging eco-innovation: a case study of the automobile industry. Journal of Cleaner Production 37, 211-220.

Schot, J. and Geels, F. W., 2008. Strategic niche management and sustainable innovation journeys: theory, findings, research agenda, and policy, Technology Analysis \& Strategic Management 20, 537-554.

Smith, A. and Raven, R., 2012. What is protective space? Reconsidering niches in transitions to sustainability. Research Policy 41, 1025-1036.

TfL, 2009. Hybrid bus customer evaluation, September 2009, TfL ref. no. 08239, London.

UITP, 2013. Buses Today \& Tomorrow. URL: http://www.uitp.org/news/pics/pdf/MB_BusesToday\&Tomorrow2.pdf (Acc. 25 March 2013)

Vergragt, P., and Brown, H.S., 2007. Sustainable Mobility: From Technological Innovations to Societal Learning, Journal of Cleaner Production 15, 1104-1115.

Visser, R., Jongen, M., Zwetsloot, G., 2008. Business-driven innovations towards more sustainable chemical products. Journal of Cleaner Production 16, S85-S94

Wells, P. and Nieuwenhuis, P., 2012. Transition failure: Understanding continuity in the automotive industry, Technological Forecasting \& Social Change 79, 1681-1692.

Yin, R., 2009. Case study research: Design and methods ( ${ }^{\text {th }}$ ed.). Sage Publishing, Thousand Oaks (CA). 


\section{Appendix: List of interviews}

\section{Manufacturers}

\begin{tabular}{|l|l|l|}
\hline Interviewee & Organisation & Year \\
\hline Senior Manager & Volvo Buses & 2012 \\
\hline Managing Director & Volvo Buses UK & 2012 \\
\hline Product Engineering Manager & Volvo Buses UK & 2012 \\
\hline Director & Volvo Advanced Technology \& Research & 2012 \\
\hline Technology manager & Alexander Dennis Buses & 2012 \\
\hline Project manager & BAE Systems & 2012 \\
\hline Manager & $\begin{array}{l}\text { Business Package Team/ Volvo Advanced } \\
\text { Technology \& Research }\end{array}$ & 2012,2009 \\
\hline Scientific Advisor & Volvo Advanced Technology \& Research & 2012,2008 \\
\hline Group manager & Major European heavy vehicle manufacturer & 2008,2011 \\
\hline $\begin{array}{l}\text { Energy Storage (Battery) } \\
\text { engineer }\end{array}$ & Volvo Technology & 2009 \\
\hline Project manager & Major European heavy vehicle manufacturer & 2009 \\
\hline Systems engineer & Major European heavy vehicle manufacturer & 2008 \\
\hline $\begin{array}{l}\text { Project Manager Hybrid } \\
\text { Development }\end{array}$ & Volvo Powertrain & 2007 \\
\hline Environmental Manager & Volvo Buses & 2001 \\
\hline
\end{tabular}

\section{Users (bus/truck operators)}

\begin{tabular}{|l|l|l|}
\hline Interviewee & Organisation & Year \\
\hline Engineering Director & Arriva, London & 2012 \\
\hline Operations Director & GS Bus, London & 2012 \\
\hline Group Technical Engineer & Stagecoach, London & 2012 \\
\hline Engineering Director & Go Ahead, London & 2012 \\
\hline Business Improvement Director & First Group, London & 2012 \\
\hline Fleet/ Operations Director & Ragn-Sells, Stockholm & 2012 \\
\hline Fleet Manager & Nobina, Stockholm & 2011 \\
\hline Vehicle Development Manager & Renova, Gothenburg & 2011 \\
\hline
\end{tabular}




\section{Technical universities}

\begin{tabular}{|l|l|l|}
\hline Interviewee & Organisation & Year \\
\hline $\begin{array}{l}\text { Director of technology } \\
\text { management program }\end{array}$ & University College of London & 2012 \\
\hline Professor in chemistry (battery) & Uppsala University & 2012 \\
\hline Professor in power electronics & Chalmers University of Technology & 2012 \\
\hline $\begin{array}{l}\text { Research coordinator for control } \\
\text { system, a professor in control } \\
\text { engineering }\end{array}$ & Swedish Hybrid Vehicle Centre & 2012,2009 \\
\hline $\begin{array}{l}\text { Professor in electric machine } \\
\text { Director, professor in } \\
\text { engineering mechanics }\end{array}$ & KTH & 2010 \\
\hline Professor in vehicular systems & Linköping University & 2009 \\
\hline
\end{tabular}

\section{Policy makers}

\begin{tabular}{|l|l|l|}
\hline Interviewee & Organisation & Year \\
\hline Operations Directors & Transport for London & 2012 \\
\hline $\begin{array}{l}\text { Environment and Climate } \\
\text { Change Coordinator }\end{array}$ & Transport for London & 2012 \\
\hline $\begin{array}{l}\text { Environment and Market } \\
\text { Strategist }\end{array}$ & Västtrafik (Västragötaland transport authority) & 2012 \\
\hline Advisor & Gothenburg Traffic Authority & 2012 \\
\hline $\begin{array}{l}\text { Project manager Clean vehicles } \\
\text { fuels programme }\end{array}$ & Stockholm Traffic Authority & 2012 \\
\hline $\begin{array}{l}\text { Manager, Sustainable } \\
\text { Development }\end{array}$ & Stockholm Public Transport (SL) & 2012 \\
\hline
\end{tabular}




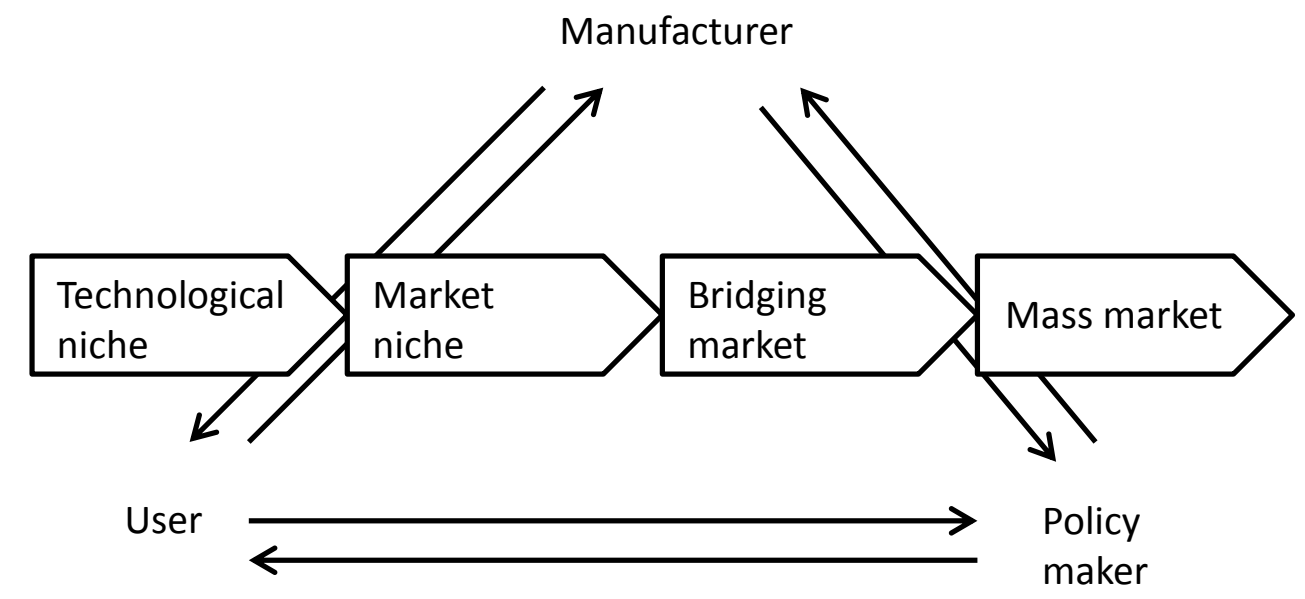

Figure 1 Temporal and structural dimensions of environmental innovation and market formation 


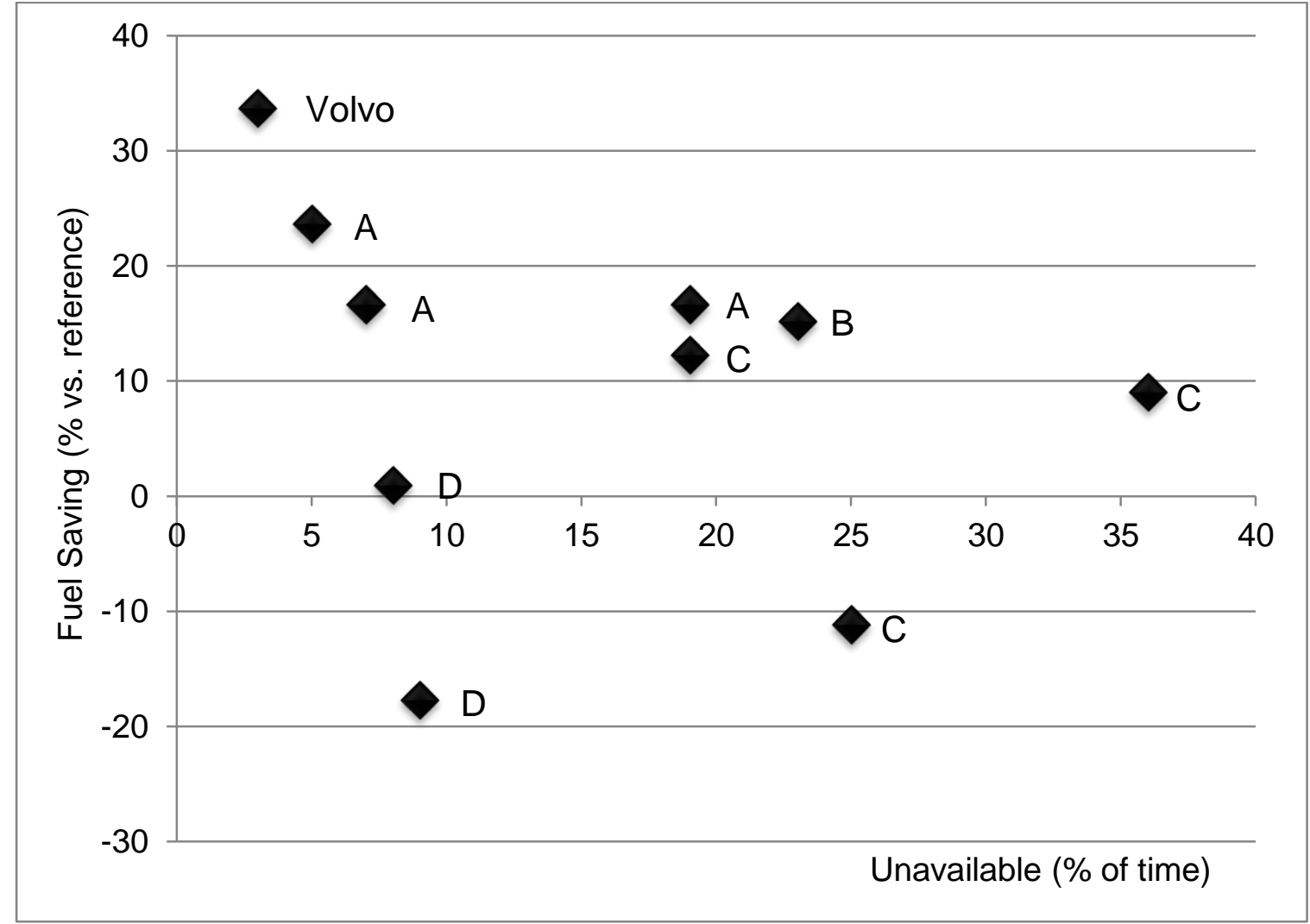

Figure 2: Results from field tests in London. A-D denotes Volvo's four competitors.

Competitors $A, C$ and $D$ have several positions in the diagram because they collaborated with several operators. (Source: $T f L$ ) 
Table 1 Feasibility for hybrid configurations in different heavy vehicle applications

\begin{tabular}{llll}
\hline Vehicle type & Series-hybrid & Parallel-hybrid \\
\hline Bus & City & Feasible & Feasible \\
& Intercity/coach & Not feasible & Feasible \\
\multirow{2}{*}{ Truck } & Distribution/refuse & Feasible & Feasible \\
& Long-haulage & Not feasible & Feasible \\
\hline
\end{tabular}


Table 2: Volvo's development and market introduction of heavy hybrid vehicles, related initiatives from policy makers and user involvement

\begin{tabular}{|c|c|c|c|c|c|c|c|c|c|c|c|}
\hline & 1995 & 1998 & 2000 & 2001 & 2002 & 2004 & 2006 & 2008 & 2010 & 2011 & 2012 \\
\hline Volvo & $\begin{array}{l}\text { Shows series- } \\
\text { hybrid concept } \\
\text { truck and bus }\end{array}$ & $\begin{array}{c}\text { Field tests of } \\
\text { series-hybrid } \\
\text { prototype truck }\end{array}$ & $\begin{array}{l}\text { Field tests of } \\
\text { series-hybrid } \\
\text { prototype bus }\end{array}$ & $\begin{array}{c}\text { Peak oil } \\
\text { study }\end{array}$ & $\begin{array}{c}\text { Advanced } \\
\text { engineering } \\
\text { parallel-hybrid }\end{array}$ & $\begin{array}{l}\text { Development, } \\
\text { field test and } \\
\text { demonstration } \\
\text { parallel-hybrid } \\
\text { prototype }\end{array}$ & $\begin{array}{c}\text { Announces } \\
\text { market } \\
\text { introduction by } \\
2009 \\
\\
\text { Initiates } \\
\text { production- } \\
\text { oriented } \\
\text { development }\end{array}$ & & $\begin{array}{c}\text { Field tests of } \\
\text { trucks and buses } \\
\text { in Gothenburg, } \\
\text { London, Paris, } \\
\text { Stockholm } \\
\text { Initiates } \\
\text { production of } \\
\text { hybrid bus }\end{array}$ & $\begin{array}{c}2^{\text {nd }} \\
\text { ver- } \\
\text { sion } \\
\text { hybrid } \\
\text { bus } \\
\text { Announ- } \\
\text { ces } \\
\text { articu- } \\
\text { lated } \\
\text { hybrid } \\
\text { bus }\end{array}$ & $\begin{array}{c}1000 \text { hybrid } \\
\text { buses sold } \\
\text { Announces } \\
\text { hybrid only } \\
\text { low-floor city } \\
\text { buses by } 2014 \\
\text { Initiates } \\
\text { development of } \\
\text { plug-in hybrid } \\
\text { bus }\end{array}$ \\
\hline
\end{tabular}

Policy

maker

User
Swedish public funding programs for automotive research, development and demonstration

Mayor of London announces 1000

hybrid buses by

2012
Department for Transport Green Bus Fund

TfL hybrid bus

field tests

involving Volvo

and 4 other

manufacturers

5 major city bus

operators

London

City bus

operator

Gothenburg

Refuse handling

companies 